\title{
Implementation of Digital Leaderships on Pertamina Hulu Energy in Aceh
}

\author{
Faisal Matriadi*, Ikramuddin, Marbawi Adamy, Chalirafi
}

Department of Management, faculty of Economics and Business, Universitas Malikussaleh, Aceh, Indonesia

*Corresponding author E-mail: fmatriadi@unimal.ac.id

Manuscript received 23 Feb 2021; revised 2 March. 2021; accepted 15 March 2021. Date of publication 2 April 2021

\section{Abstract}

This study examines the effect of Digital Leadership and workplace spirituality on the performance of Pertamina Hulu energy employees with job satisfaction as an intervening variable. A population of 136 employees were all used as respondents or using a saturated sample model. The analytical tool used is the SEM (structural equation modeling) method using Amos. The results showed that each variable, both digital leaderships and workplace spirituality, had a positive and significant effect on job satisfaction and employee performance at Pertamina Hulu Energy. Furthermore, the job satisfaction variable mediates workplace spirituality with the performance variable partially mediating and the job satisfaction variable mediating digital leaderships with the performance variable. also partially mediation.

Keywords: Workplace spirituality, Digital Leaderships, Work Satisfaction, and Employee Performance.

\section{Introduction}

Digital leaderships is an issue that is currently interesting to be researched in the current era full of digitalization. Digital leaderships will overcome the issue of conventional leadership that has not used digital as the main competency of leaders. This digitalization condition is interesting because its dimensions are very important in the modern era. Digital leaderships is a concept that must be applied by modern IT-based leaders. Without an understanding and mastery of IT, leaderships in the modern era will be left behind and will lose out compared to other parties who have adopted digital leadership competencies. Likewise, workplace spirituality is an important thing that will improve company performance. Performance will have an impact on profits and also the sustainability of a business from an organization or company. There are so many studies that focus on measuring the performance of companies and the performance of government organizations and even social organizations. However, talking about the performance of companies engaged in the oil and gas sector is certainly something more interesting because the performance of oil and gas companies is determined by many things, and digital leaderships and workplace spirituality are factors that determine the performance of oil and gas companies.

One of the variables that greatly affect performance that is currently very intensely discussed by researchers is digital leaderships and workplace spirituality. Spirituality Workplace. Workplace spirituality is closer to a humanistic pattern that treats humans very humanely. Workplace Spirituality is an important concept that can contribute to the well-being of individuals, organizations and society. While the benefits that can be derived from organizational Spirituality have been supported by several studies (Daniel, 2010; Ferreira-Vasconcelos, 2010; Garcia-Zamor, 2003), it has also been shown that Workplace Spirituality is still in its early stages and requires more theoretical and empirical research. (Milliman, Czaplewski, \& Ferguson, 2003).

The phenomenon of job satisfaction shows that some Pertamina Hulu Energy NSB employees are different from the satisfaction level of Mobil Oil or Exxonmobil employees who previously managed oil and gas in Aceh. The level of job satisfaction is also certainly related to various aspects that exist in the internal organization. Luthans (2011) argues that job satisfaction is the result of employees' perceptions of how well their work delivers what is considered important, Suwatno and Priansa (2011) argue that job satisfaction is the way individuals feel about the work they produce.

Wang and Ho (2012), job satisfaction refers to a person's emotional attitude or tendency towards work. Basically this view shows that job satisfaction is the level of individual preference for the job. This view is supported by Oshagbemi (2000). Usman et al. (2011) explained that job satisfaction is an individual's positive feeling towards a job. As for Chatzoglou et al. (2011) stated that job satisfaction is an expression of individual feelings towards work and affects the functioning of the organization. When an employee feels job satisfaction, of course he will do his best to complete his work. Job satisfaction is certainly influenced by various factors, including working conditions, organizational and management supervision, opportunities for salary increases, and the availability, incentives, and benefits in other financial fields.

One of the variables that greatly affect performance that is currently very intensely discussed by researchers is digital leaderships and workplace spirituality. Spirituality Workplace. Workplace spirituality is closer to a humanistic pattern that treats humans very humanely. 
Workplace Spirituality is an important concept that can contribute to the well-being of individuals, organizations and society. While the benefits that can be derived from organizational Spirituality have been supported by several studies (Daniel, 2010; Ferreira-Vasconcelos, 2010; Garcia-Zamor, 2003), it has also been shown that Workplace Spirituality is still in its early stages and requires more theoretical and empirical research. (Milliman, Czaplewski, \& Ferguson, 2003).

The phenomenon of job satisfaction shows that some Pertamina Hulu Energy NSB employees are different from the satisfaction level of Mobil Oil or Exxonmobil employees who previously managed oil and gas in Aceh. The level of job satisfaction is also certainly related to various aspects that exist in the internal organization. Luthans (2011) argues that job satisfaction is the result of employees' perceptions of how well their work delivers what is considered important, Suwatno and Priansa (2011) argue that job satisfaction is the way individuals feel about the work they produce.

Wang and Ho (2012), job satisfaction refers to a person's emotional attitude or tendency towards work. Basically this view shows that job satisfaction is the level of individual preference for the job. This view is supported by Oshagbemi (2000). Usman et al. (2011) explained that job satisfaction is an individual's positive feeling towards a job. As for Chatzoglou et al. (2011) stated that job satisfaction is an expression of individual feelings towards work and affects the functioning of the organization. When an employee feels job satisfaction, of course he will do his best to complete his work. Job satisfaction is certainly influenced by various factors, including working conditions, organizational and management supervision, opportunities for salary increases, and the availability, incentives, and benefits in other financial fields.

The problems in this study are (1) How is the influence of Workplace Spirituality on the job satisfaction of Pertamina Hulu Energy NSB employees? (2). How is the influence of leadership on the job satisfaction of Pertamina Hulu Energy NSB employees?. (3). How is the influence of Workplace Spirituality on the performance of Pertamina Hulu Energy NSB employees?. 4. How is the influence of leadership on the performance of Pertamina Hulu Energy NSB employees?. (5) How does job satisfaction affect the performance of Pertamina Hulu Energy NSB employees? (6). Does job satisfaction mediate the influence of workplace spirituality on the performance of Pertamina Hulu Energy NSB employees? Dan (7). Does job satisfaction mediate the influence of leadership on the performance of Pertamina Hulu Energy NSB employees?.

\section{Literature Review}

Leadership is the process of mobilizing people in an organization because they have the power, authority and ability to work in a high ethical environment and complete their work happily according to the expected results (Salam, 2002). According to Silalahi (2002), leadership is an activity that influences the behavior of others, both individually and in groups, in order to carry out activities to achieve a goal in certain situations.

Digital leaderships is how a leader has perfect access to valid information as the basis and basis for making decisions that will determine the company's competitiveness. Access to valid information can be done with good IT usage skills. So digital leadership is not just about the ability to use social media such as websites and email but how to use data as an important part for companies in decision making. Indicators in digital leaders are (1) Critical thinking on Problem Solving, (2) Creativity, (3) Communication Skills and (4) Ability to Work Colloratively. (Wade, 1995)

Workplace spirituality is an approach that emerged in the 1920s and has its roots in the field of humanistic psychology (McGuire, Cross, \& O'Donnell, 2005). The increasing interest in humanism is due to a shift in management style in organizations. Organizations recognize the important role that employees play in the company and move from a tough, rigid, bureaucratic management style to a people-oriented or humanistic style (Aldridge, Macy, \& Walz, 1982; Argyris, 1964; Henderson, 1996). Humanistic theory can explain this shift will make the organization better than before.

Martin, et al (Team and Chunha, 2008) stated that the application of workplace spirituality will stimulate employees to form a more positive perception of the organization so that employees will get change and achieve better adjustments through work with higher satisfaction, commitment to the organization, organizational well-being, and low turnover and absenteeism.

McClelland (1961) and McGregor (1960) also contributed to the growth of the humanistic approach. McClelland (1961) noted that humans are motivated by three needs: the need for achievement, the need for power, and the need for affiliation. He also pointed out that the environment has an important influence on the motivation of each individual. Mitroff and Denton (1999a) mention that workplace spirituality is about finding purpose in life, creating strong relationships with coworkers and having a match between core individual values and organizational values. Ashmos and Duchon (2000) also state that workplace spirituality involves a sense of community. They define workplace spirituality as "the recognition that employees have an inner life that nourishes and is nurtured by meaningful work that takes place in a community context" (p.137). They developed a scale to measure workplace spirituality, and identified individual, group and organizational factors. They found that workplace spirituality can be seen as a range of aspects of connectedness, meaningful work and the integration of individual life with work activities. They also note that these aspects are relevant in establishing workplace spirituality measures. In general, the flow of workplace spirituality can be described as follows:

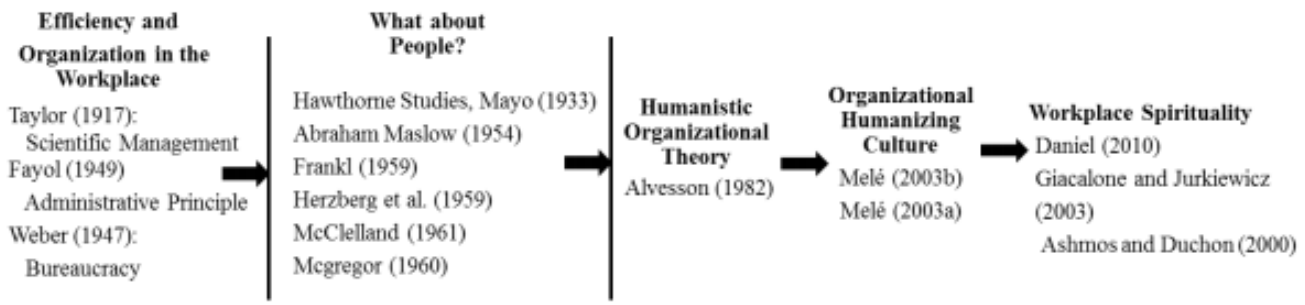

Fig 1. Mumanistic approach

Resource: Jose Luis Daniel

Laabs (1995) also notes that the individual is more than just mind and body; they have special spirits and gifts. Marques (2007) also supports the view that the two concepts are different. He points out that religion refers to "an established mindset, held by one or more individuals regarding practices and values that they deem appropriate" (Marques, 2007. Regarding spirituality, he states that it is about 
personal emotions that determine one's perspective on, and with respect to, self, other people, and the universe. Mitroff (2003) interviewed high-level managers and executives about the relationship between spirituality and religion. According to their results, most people distinguish between religion and spirituality. The indicators of Workplace Spirituality are (1) Mystical Values (2) The Value of a Job (Meaning of Work) (3) A sense of togetherness (4) Alignment with organizational values.

Luthans (2011) emphasizes that job satisfaction is the result of employees' perceptions of how well their work provides what is considered important, Suwatno and Priansa (2011) explain that job satisfaction is the way individuals feel about their work. individual attitudes towards various aspects involved in work. Meanwhile, according to Robbins (2015) states that job satisfaction is a general attitude towards one's work because of the difference between the amount of reward received by employees and the amount of reward that is believed to be received. In addition, according to Priansa (2014) job satisfaction is the feeling of employees towards their work or the perception of mental attitudes and work results of employees, whether happy or unhappy due to employee interactions with the work environment. job evaluation. Robbins (2015) states that there are several indicators that determine job satisfaction, namely (1). Mentally challenging work, (2) Good working conditions, (3) Fair wages and (4) Harmony of personality in the workplace and (5) Supportive coworkers

The definition of performance is basically an activity and result that can be achieved or carried out by a person or group of people while carrying out their duties, while working well; This means that they achieve or even exceed predetermined goals or work standards. standards set by the company within a certain period of time (Handoko, 2005). Based on several definitions of performance described, researchers can conclude that performance is a measure of the quality of an employee's work when completing his or her duties. According to Munadia et al. (2015) states that employee performance is measured by 5 (five) indicators, namely (1) Quality, (2) Quantity of work (3) Timeliness (4) Effectiveness and (5) Independence.

\section{Methods}

The research framework can be explained in Figure 2 below:

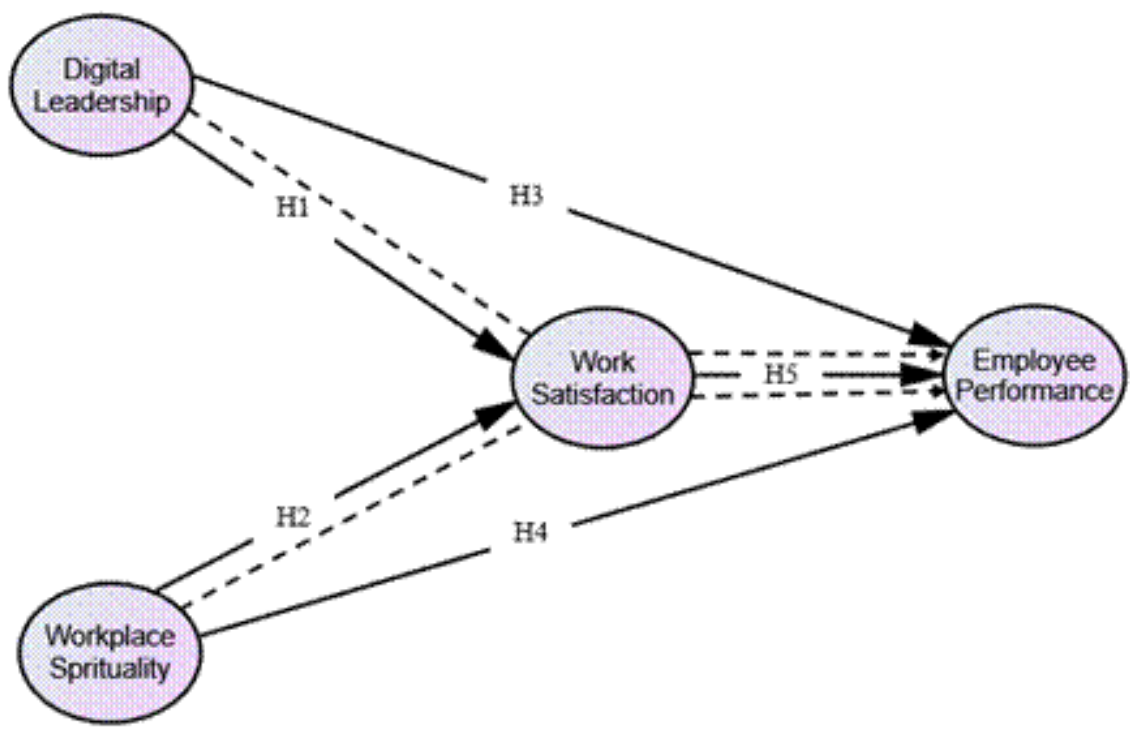

Fig 2. Conceptual Framework

The population in this study were PHE NSB employees in North Aceh, totaling 136 people. All populations are sampled. In this study, the authors used a Likert scale to measure the influence of digital leaderships, workplace spirituality on job satisfaction of PHE NSB employees, and the variables to be measured were seen from several indicators.

\section{Results and Discussion}

The results of data processing indicate that all of the constructs used to form this research model have not met the criteria goodness of fit index that has been determined such as chi-square value, GFI value, RMSEA, AGFI, TLI, CFI, and CMIN/DF values. that not all Goodness Of Fit (GOF) values have not met the required criteria, for example the GFI value is still marginal $(0.876<0.90)$, the AGFI value is also still marginal $(0.839<0.90)$ and the p-value is also still bad because below 0.05 . Thus the research model is not appropriate and has not been able to explain the research model properly and well, so that the model needs to be modified.

The results of the full model test after modification are shown in Figure 3 below:

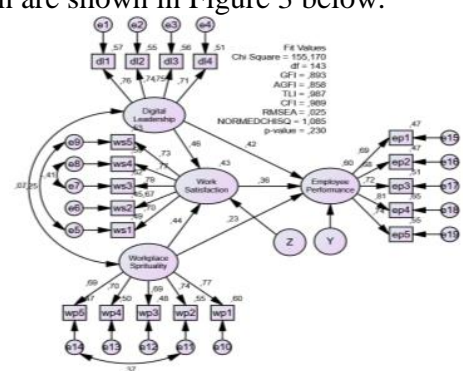

Fig 3. Full Model After Modification

Source: Amos Output, 2021 
After being modified in general, all the constructs used to form this research model, have met the criteria of goodness of fit index that have been determined such as chi-square value, GFI value, TLI value, CFI value, RMSEA, CMIN/DF and p-value except AGFI and GFI values are still marginal but are close to the cut off value and this value is considered good when referring to some previous expert opinions. Statistical tests were carried out by observing the significance level of the relationship between variables which was shown through the C.R (Critical Ratio) value which was identical to the t-test in the regression and the probability value $(\mathrm{P})$ or the significance test. A significant relationship is indicated by the C.R value greater than 2.58 and the P value less than 0.05 (Ferdinand, 2014). To see how much influence exogenous variables (digital leaderships and workplace spirituality variables) have endogenous (job satisfaction and employee performance) are shown in Table 1, below:

Table 1. Effect of Exogenous Variables on Endogenous Variables

\begin{tabular}{lllrrrrr}
\hline & & & Estimate & $\begin{array}{c}\text { Stand. } \\
\text { Estimate }\end{array}$ & S.E. & C.R. & P \\
\hline Kepuasan_Kerja & $<---$ & Digita Leaderships & 0,396 & 0,44 & 0,086 & 4,621 & $* * *$ \\
Kepuasan_Kerja & $<---$ & Workplace_Sprituality & 0,411 & 0,456 & 0,089 & 4,629 & $* * *$ \\
Kinerja_Pegawai & $<---$ & Kepuasan_Kerja & 0,317 & 0,361 & 0,104 & 3,045 & 0,002 \\
Kinerja_Pegawai & $<---$ & Digital Leaderships & 0,185 & 0,234 & 0,077 & 2,415 & 0,016 \\
Kinerja_Pegawai & $<---$ & Workplace_Sprituality & 0,329 & 0,415 & 0,084 & 3,935 & $* * *$ \\
\hline Source: Amos Output, 2021 & & & & & & &
\end{tabular}

Based on Table 1, the explanation can be explained that the influence of Digital Leadership on Job Satisfaction is significant with a coefficient of estimate standardized regression weight of $0.440(44.0 \%)$, a probability or significance value of $0.000 * * *$ (significant) and a CR value of 4.621 ( accept H2). The influence of Workplace Spirituality on Job Satisfaction is significant with the estimated standardized regression weight coefficient value of $0.456(45.6 \%)$, the probability or significance value of $0.000 * * *$ (significant) and the C.R value of 4.629 (accept H1). The influence of Workplace Spirituality on Employee Performance is significant with the estimated standardized regression weight coefficient of $0.415(41.5 \%)$, the probability or significance value of $0.000 * * *$ (significant) and the C.R value of 3.935 (accept H3). The influence of Digital Leaderships on Employee Performance is significant with a coefficient value estimate standardized regression weight of 0.234 (23.4\%), a probability or significance value of 0.016 (significant) and a CR value of 2.415 (accept H4). The effect of Job Satisfaction on Employee Performance is significant with the estimated standardized regression weight coefficient value of $0.361(36.1 \%)$, the probability or significance value of 0.002 (significant) and the CR value of 3.045.

The results of testing the effect of mediating (intervening) on the relationship between the Digital leaderships variable (predictor variable) on employee performance (outcome variable) mediated by job satisfaction (mediation variable) can be seen from the calculation of the significance value of the -c' path using software. The calculation of the coefficients of the $-\mathrm{a},-\mathrm{b},-\mathrm{c}$ paths are significant and the -c' paths are also significant. In other words, the variable of job satisfaction partially mediates the influence of digital leaderships on the performance of PT. Pertamina Hulu Energy. Furthermore, the coefficients of the $-\mathrm{a},-\mathrm{b},-\mathrm{c}$ paths are significant and the -c' paths are also significant. In other words, the variable of job satisfaction partially mediates the influence of workplace spirituality on the performance of PT. Pertamina Hulu Energy.

\section{Conclusion}

Based On The Problem Formulation, Objectives And Research Hypotheses That Have Been Described Previously, Several Conclusions Can Be Drawn In This Study, Namely (1) Digital Leaderships And Workplace Spirituality Have A Significant Effect On Job Satisfaction Of Pt. Pertamina Hulu Energi, (2) Digital Leaderships And Workplace Spirituality Have A Significant Effect On The Performance Of Pt. Pertamina Hulu Energi, (3) Job Satisfaction Has A Significant Effect On The Performance Of Employees Of Pt. Pertamina Hulu Energy. (4) Job Satisfaction Mediates The Relationship Between Digital Leaderships And Workplace Spirituality On The Performance Of Pt. Pertamina Hulu Energi. Management Of Pt. Pertamina Hulu Energi Is Expected To Increase The Spiritual Values Of Employees In The Workplace, Especially Those Related To The Alignment Of Individual Values With Organizational Values. Then The Management Of Pt. Pertamina Hulu Energi Is Expected To Be Able To Improve Digital Leadership Capabilities In Every Part Of The Organization, So That It Can Have An Effect On Increasing Employee Performance, Especially Those Related To Indicators Of The Leader's Ability To Mobilize Organizational Resources To Produce High Organizational Performance. In Addition, The Management Of Pt. Pertamina Hulu Energi Is Expected To Be Able To Increase Employee Job Satisfaction, Especially Those Related To Indicators Related To Improving The Atmosphere Or Conditions Of The Workplace. A Conducive Working Environment Will Have An Impact On The High Performance Of Pt. Pertamina Hulu Energi In North Aceh Regency, And Finally The Management Of Pt. Pertamina Hulu Energi Is Expected To Improve Employee Performance By Improving The Quality And Quantity Of Work, Time Discipline, Effectiveness Of Resource Use And Independence Of Employees And Organizations, Especially Those Related To The Quantity Of Work Delegated To Each Employe.

\section{References}

[1] Baron, R. M. \& D. A. Kenny, (1986), The Moderator-Mediator Variable Distinction in Social Psychological Research: Conceptual, Strategic And Statistical Considerations, Journal of Personality and Social Psychology, pp. 1173-1182.

[2 ] Basit, A., Sebastian, V., \& Hassan, Z. (2017). Impact of Leadership style on Employee Performance (a case study on a private organization in Malaysia). International Journal of Accounting \& Business Management, 5(2), 112-130.

[3 ] Brett, J. M., Tinsley, C. H., Janssens, M., Barsness, Z. I., \& Little, A. L. (1997). New approaches to the study of culture in I/O psychology. In P. C. Earley \& M. Erez (Eds.), New Perspectives on International/Organizational Psychology (pp. 75-129). San Francisco, CA: Jossey-Bass.

[4 ] Brown, R. (2003a). Organizational spirituality: The sceptic's version. Organization, 10(2), 393- 400. Brown, W., \& Yoshioka, C. (2003b). Mission attachment and satisfaction as factors in employee retention. Nonprofit Management and Leadership, 14(1), 5-18.

[5 ] Burack, E. H. (1999). Spirituality in the workplace. Journal of Organizational Change Management, 12(4), $280-292$. 
[6 ] Daniel, J. (2010). The effect of workplace spirituality on team effectiveness. Journal of Management Development, 29(5), 442-456.

[7 ] Dehler, G. E., \& Welsh, M. A. (1994). Spirituality and organizational transformation: Implications for the new management paradigm. Journal of Managerial Psychology, 9(6), 17-26.

[8 ] Duchon, D., \& Plowman, D. A. (2005). Nurturing the spirit at work: Impact on work unit performance. The Leadership Quarterly, 16(5), 807-833.

[9] Dubrin, Andrew J. 2005. Leadership (Terjemahan. Edisi Kedua. Prenada Media. Jakarta.

[10 ] Fairholm, G. W. (1996). Spiritual leadership: Fulfilling whole-self needs at work. Leadership \& Organization Development Journal, 17(5), 11-17.

[11 ] Ferdinand A, 2002. Structural Equation Modelling Dalam Peneltian Manajemen. Edisi 2, Seri Pustaka Kunci 03/BP UNDIP.

[12 ] Ferreira-Vasconcelos, A. (2010). Spiritual development in organizations: A Religious-based approach. Journal of Business Ethics, 93(4), 607-622.

[13 ] Garcia-Zamor, J.-C. (2003). Workplace spirituality and organizational performance. Public Administration Review, 63(3), 355-363.

[14 ] Giacalone, R., \& Jurkiewicz, C. L. (2003). Toward a science of workplace spirituality , in R. A. Giacalone \& C. L. Jurkiewicz (eds), The handbook of workplace spirituality and organizational performance (pp. 3-28). Armonk, NY: M.E. Sharpe.

[15 ] Gotsis, G., \& Kortezi, Z. (2008). Philosophical foundations of workplace spirituality: A critical approach. Journal of Business Ethics, $78(4), 575-600$

[16 ] Hofstede, G. (2001). Culture's consequences: Comparing values, behaviors, institutions, and organizations across nations (2nd ed.). Thousand Oaks, CA: Sage.

[17 ] Jurkiewicz, C. L., \& Giacalone, R. A. (2004). A Values framework for measuring the impact of workplace spirituality on organizational performance. Journal of Business Ethics, 49(2), 129-142. 86

[18 ] Kouzes, J. M., \& Posner, B. Z. (1995). The leadership challenge: How to keep getting extraordinary things done in organizations (2nd ed.). San Francisco, CA: Jossey-Bass.

[19] Krishnakumar, S., \& Neck, C. P. (2002). The "what", "why" and "how" of spirituality in the workplace. Journal of Managerial Psychology, 17(3), 153-164. 87

[20 ] Kumar, V., \& Deregowska, D. (2002). Latent structural modeling: Choosing between structural equation modeling and partial least squares. Administrative Sciences Association of Canada, 23, 1-10.

[21 ] Laabs, J. (1995). Balancing spirituality and work. Personnel Journal, 74(9), 60-76.

[22 ] Marques, J. (2007). The reciprocity between spirituality in the workplace and thinking outside the box. The Business Renaissance Quarterly, 2(3), 93-117.

[23 ] Mayfield, M., \& Mayfield, J. (2008). Leadership techniques for nurturing worker garden variety creativity. Journal of Management Development, 27(9), 976-986.

[24 ] McMillan, D., \& Chavis, D. (1986). Sense of community: A definition and theory. Journal of Community Psychology, 14, 6-23.

[25 ] Milliman, J., Czaplewski, J., \& Ferguson, J. (2003). Workplace spirituality and employee work attitudes: An exploratory empiriassessm cal ent. Journal of Organizational Change Management, 16(4), 426-447. 89

[26] Mitroff, I. (2003). Do not promote religion under the guise of spirituality. Organization, 10(2), 375-382.

[27 ] Pawar, B. S. (2009). Individual spirituality, workplace spirituality and work attitudes: An empirical test of direct and interaction effects. Leadership \& Organization Development Journal, 30(8), 759-777.

[28 ] Pfeffer, J., \& Veiga, J. F. (1999). Putting people first for organizational success. The Academy of Management Executive (19932005), 13(2), 37-48

[29] Rego, A., \& Cunha, M. (2008). Workplace spirituality and organizational commitment: an empirical study. Journal of Organizational Change Management, 21(1), 53-75.

[30 ] Robert, T. E., Young, J. S., \& Kelly, V. A. (2006). Relationships between adult workers' spiritual well-being and job satisfaction: A preliminary study. Counseling and Values, 50(3), 165- 175. 91 Schwartz, S. H. (1994). Beyond individualism and collectivism: New cultural dimensions of values. In U. Kim, H. C. Triandis, C. Kagitcibasi, S.-C. Choi \& G. Yoon (Eds.), Individualism and collectivism: Theory, method and applications (pp. 85-119). Newbury Park, CA: Sage.

[31 ] Sheep, M. (2006). Nurturing the whole person: The ethics of workplace spirituality in a society of organizations. Journal of Business Ethics, 66(4), 357-375.

[32 ] Steele, J., \& Bullock, E. (2009). A review of spirituality in the workplace. Employee Responsibilities and Rights Journal, 21(3), 273274.92

[33 ] Strack, G., \& Fottler, M. D. (2002). Spirituality and effective leadership in healthcare: Is there a connection?. Frontiers of Health Services Management, 18(4), 3-18.

[34 ] Robbins, Stephen P. (2015). Perilaku Organisasi. Jakarta Selatan: Salemba Empat

[35 ] Sobel, M. E. (1982). Asymptotic confidence intervals for indirect effects in structural equation models. In Sociological Methodology, edited by Leinhardt, S., 290-312. Washington D. C.: American Sociological Association.

[36] Townsend, J. (2000). Creativity in the workplace. In D. Clements-Croome (Ed.), Creating the Productive Workplace (pp. 18-28). London, England: Taylor and Francis.

[37 ] Trott, D. C. (1996). Spiritual well-being of workers: An exploratory study of spirituality in the workplace. Austin, TX: University of Texas. 